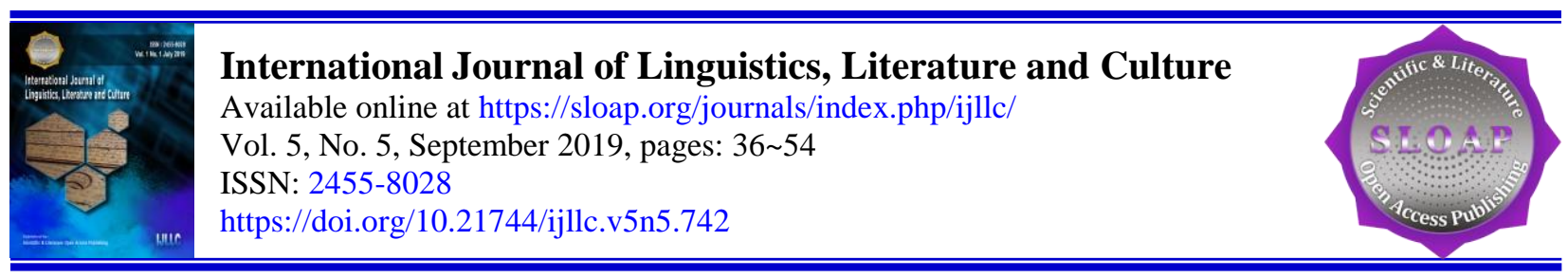

\title{
Toni Morrison's Poetics of Intertextuality or the Supreme Art of Borrowing
}

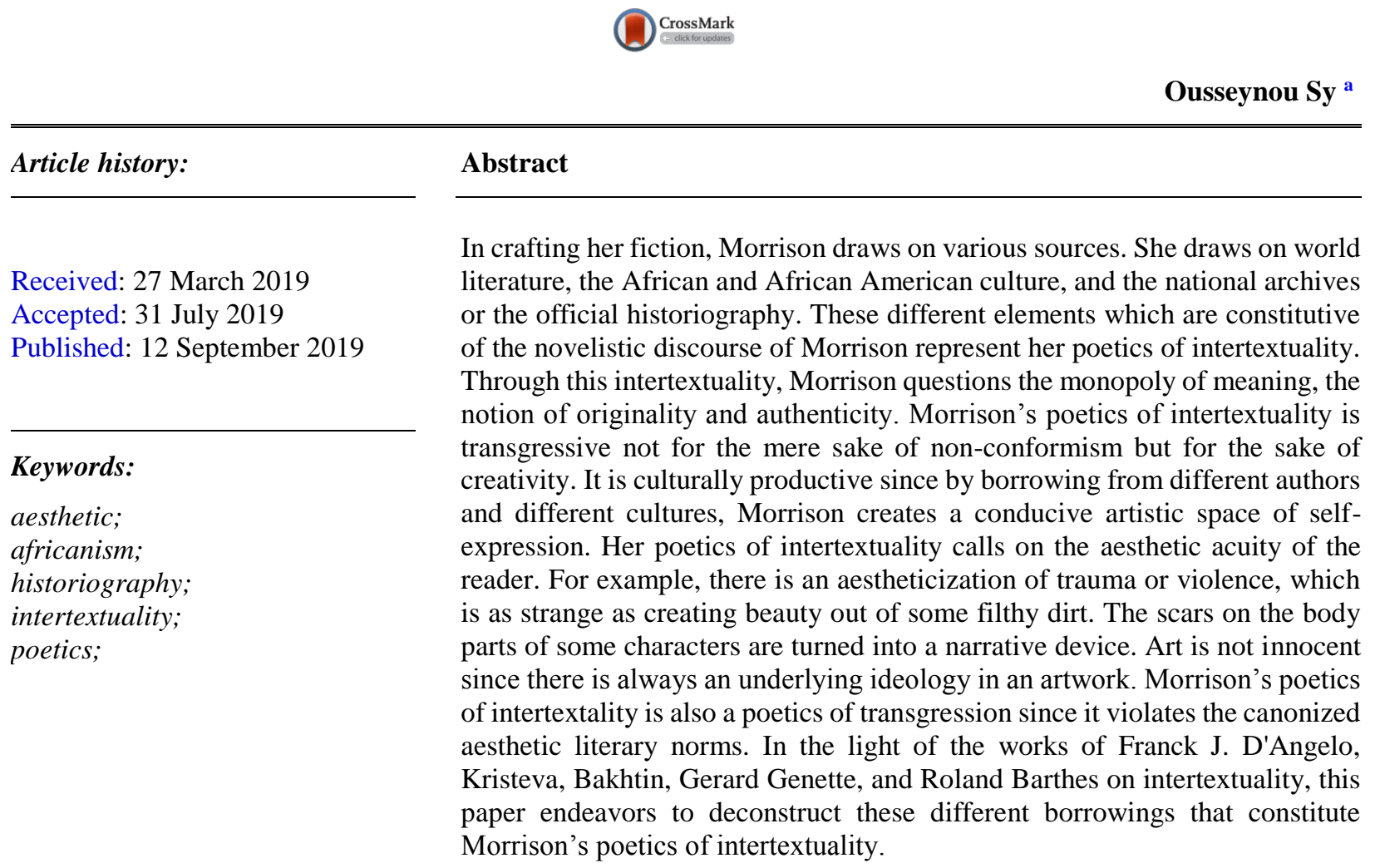

2455-8028 ${ }^{\circ}$ Copyright 2019. The Author. This is an open-access article under the CC BY-SA license (https://creativecommons.org/licenses/by-sa/4.0/) All rights reserved.

Author correspondence:

Ousseynou Sy,

Sahel University, Dakar, Senegal.

Email address: ousseynousy2002@yahoo.fr / ousseynou2002@gmail.com

\section{The Reviewed Summary}

The frontiers of a book are never clear-cut: beyond the title, the first lines, and the last full-stop, beyond its internal configuration and its autonomous form, it is caught up in a system of references to other books, other texts, other sentences: it is a node within a network. (210), Michael Foucault. Language, Counter-Memory, Practice.

a Sahel University, Dakar, Senegal 
The idea of bridging home (Africa) with the transplanted home (America) gives rise textually to an intertextuality in Morrison's narratives (Mohan \& Kumar, 2018). And as Peterson explains in her essay, "Say Make Me, Remake Me:" "Morrison's historical novels are structured recursively: that is, the narration of present events is continually interrupted by the telling of "background" stories." (205) Peterson invites us to look at the recursive dimension of Morrison's texts. Beyond the recursive structure lies a palimpsest narrative. There are many stories that are interwoven. Rarely does Morrison weave a single story without building on another story or alluding to another story or other stories. And this overlap of stories creates a sophisticated layer of intertextuality (Mahyudi et al., 2017; Mohan et al., 2018).

Another layer of intertextuality occurs in the memories and bodies of the characters. The bodies and memories of the characters function as texts on which Morrison endeavors to dust off a civilization that has been overwritten into non-existence as Jennings reminds us (Gates, 2014; Gérard 1982; Gray, 1998). For example, Jennings explains that the cross and the circle or the cross within the circle refer, according to the Dahomey's Vodun, to "the signage under which the creolizing of West and Central African traditional regions occurred in Haiti's Voudoun" (2), and that's exactly the sign that Beloved has. Beloved has a mark: "a circle and a cross" on her right rib. These textualized bodies and memories turn Morrison's narratives into a testimonio genre (Graham, 2000; Baker 2013; Bakhtin, 2010).

There are also undertones of science fiction in Morrison's narrative. Home is modeled after a science fiction with the images of bodies being operated on and injected substances. Also, the blues and the jazz are oral forms that act upon the text. Overall, the recursive and palimpsest narrative, the textualized memories and bodies, and the textualized blues and jazz offer a pyramid of intertextuality in Morrison's fiction that this paper attempts to deconstruct. These various forms of intertextuality is what is referred to as the poetics of intertextuality (Nadel, 1988; Nora, 1989; Phelan, 1993; Porter, 1986). The thematic intend of this poetics of intertextuality is to produce a discourse that subverts and disputes the notion of originality and authenticity. In other words, through this poetics of intertextuality, Morrison subverts not only the received American history or the official historiography but also the novel creation process. The interwoven stories or palimpsest narrative, the textualized bodies, the African resonance, and the science fiction elements in Morrison's texts are the object of study in this paper. It analyzes the hybrid genre that Morrison produces at the end of the day (Guth, 1993; Hirsch, 2008; Razmi \& Jamali, 2012). To Morrison, intertextuality is a process of doing language, which is the ultimate meaning of life as she writes in her nobel lecture: "We die. That may be the meaning of life. But we do language. That may be the measure of our lives." (3) By borrowing from different authors, different genres, and different traditions, Morrison creates her language of intertextuality.

But before analyzing Morrison's poetics of intertextuality, let us just have a literature review of intertextuality. What is intertextuality? What does it entail? And how does it manifest itself in a piece of fiction?

In "The Rhetoric of Intertextuality" Franck J. D'Angelo, quoting renowned scholars of literary criticism like Kristeva and Bakhtin, makes the following remark about intertextuality:

\begin{abstract}
According to many critics, the term intertextuality was coined by Julia Kristeva. For example, in Revolution in Poetic Language, Kristeva defines intertextuality as "the transposition of one (or several) sign system(s) into another."And in "Word, Dialogue, and Novel," referring to the work of Mikhail Bakhtin, which she introduces into French literary criticism, Kristeva comments that "any text is constructed as a mosaic of quotations; any text is the absorption and transformation of another." In other words, every text is connected to other texts by citations, quotations, allusions, borrowings, adaptations, appropriations, parody, pastiche, imitation, and the like. Every text is in a dialogical relationship with other texts. In sum, intertextuality describes the relationships that exist between and among texts. (33)
\end{abstract}

The language of intertextuality in Morrison's narrative bears all these characteristics. Besides the intertextuality in her narrative, like all intertextuality, is meant to better win over the adherence of the reader's mind and attention. D'Angela discusses a few strategies of intertextuality. Among these strategies, we can mention: adaptation, appropriation, parody, pastiche, and simulation. Adaptation can cover a wide range of communication media and can happen in many forms. Adaptation is the most outstanding feature of intertextuality in Morrison's text. D'Angelo defines adaptation as "... the recasting or blending of a rhetorical text into a new form" (34). D'Angelo further clarifies, "adaptation is the modification of artistic material transposed from one genre to another." (33-34) The definitions of adaptation that D'Angelo provides fit Morrison's text. The blues and jazz exemplify adaptation. The blues and jazz are the adapted texts that are transposed to the novel discourse (Bakhtin, 1996; Byala, 2008; Camp et al., 2016).

Also, the Africanism in Morrison's narrative is an element of borrowing. And the explict references to some historical events in her text is a form of borrowing and adaptation because we can argue that there is some sort of historical enactment. This historical enactment is the pretext around which the story of Beloved is built: Margaret

Sy, O. (2019). Toni morrison's poetics of intertextuality or the supreme art of borrowing. International Journal of Linguistics, Literature and Culture, 5(5), 36-54. https://doi.org/10.21744/ijllc.v5n5.742 
Garner's murder of her daughter to save her from the trauma of slavery. In the same vein, Home enacts the Tuskegee Syphilis study. In sum, through adaptation Morrison revisits some pages of the American historiography (Jennings, 2010; Landow, 1997; Mengel \& Borzaga, 2012). If the reader is familiar with the adapted history, he or she can draw a long list of intertextuality between the adapted histories and their referents in the official historiography. Adaptation is, then, the means through which Morrison pastiches the past and parodies the official historiography (Cissé, 2010; Conrad, 2007; Conrad, 2008).

The other mode of intertextuality that D'Angelo discusses that squares with Morrison's fiction is appropriation. He defines appropriation, quoting Lisa Cartwright and Marita Sturken, as "the act of borrowing, stealing, or taking over others' meanings to one's own ends." (36) Morrison resorts to this intertextuality of appropriation to enable several characters in Beloved to tell and retell the birth history of Denver. Yet in Morrison's text, it is almost impossible to draw a fine line between appropriation and adaptation. In fact, she appropriates and adapts the mainstream American narrative. The appropriation and adaptation go hand in hand. They are used simultaneously in her craft for a very specific purpose. Appropriation allows Morrison to claim the agency to rewrite the history of her community bringing to the fore the African American perspective, and the adaptation makes her correct the omissions and erasures stemming from the official historiography (D'Angelo, 2009; Bradley, 1981; Faris et al., 1977).

By combining appropriation and adaptation in her poetics of intertextuality, Morrison produces a novelistic discourse that rejects the notion of originality and authenticity. To Morrison, there is no monopoly of meaning as she articulates eloquently in her nobel lecture by assigning different meanings to language. Also, to Morrison every history is pluri-meaning because constructed for one's own particular agenda, and thereby open to interpretation. Her novel may be called a pastiched genre that is to say a genre in which the adapted text / history constitutes the core of the narrative (Alan, 2012; Slemon, 1988; Visser, 2011). Whether she admits it or not, the adapted or appropriated text is the backbone of the story and is necessary for the progress of the narrative. For example, without the Margaret Garner murder story, Beloved wouldn't exist. The Margaret Garner story is the adapted or appropriated narrative that Morrison alters slightly and intertwines with other stories. In the same vein, Home is the adapted or appropriated narrative of the Tuskegee Syphilis study. The Tuskegee Syphilis Study is a study in which American physicians deliberately injected syphilis and other diseases into African Americans to see how these diseases would evolve over time in humans. This research project was funded by the U.S.A government. In her interview with Torrence Boone (as reported by Laura Castor), Morrison mentions the Tuskegee Syphilis Study in these terms:

Among the most notorious experimentation on helpless people and the one that Morrison mentions as having directly influenced the development of Home was the Tuskegee Study, a government-initiated project designed to observe the progression of syphilis. From 1932 to 1972, 399 African American men with the disease, and 201 who did not have it, were unknowingly made subjects of this study. While those inflicted with syphilis were told that they were being treated for "bad blood," U.S. Public Health Service officials were consciously withholding treatment from them. (141)

Morrison appropriates and adapts this historical event while deliberately leaving out some elements in her fiction. She leaves out the law suit against the $\mathrm{d}$ octors, President Bill Clinton's apology, and the reparation issues. By enacting only the core element of the Tuskegee Syphilis Study, Morrison exposes her art of borrowing. If Morrison borrowed and rendered textually the Tuskegee Syphilis Study, that would be too simple an approach to be called poetics or art since simplicity is art but too much simplicity is no longer art (Yúdice, 1991; Mahyudi et al., 2017).

Similarly, reconsidering the importance of jazz and blues in Jazz or Sula in the narrative economy, we can elaborate that the blues and jazz stand for the appropriated or adapted narrative. In comparing adaptation with appropriation, D'Angelo writes: "To many critics, the biggest difference between adaptation and appropriation is that the adaptor acknowledges a prior text whereas the appropriator does not, often taking a prior text without permission." (36) In the light of this quotation, Morrison is at the same time an adaptor and an appropriator. Some intertextuality lies always there in her narrative, it behoves to the reader to pinpoint the adapted or appropriated text or history.

Another device of intertextuality that D'Angelo mentions in the cited quotation is pastiche. Drawing on The American Heritage Dictionary and Allen Graham's book Intertextuality, D'Angelo defines pastiche as a "word or style produced by borrowing fragments, ingredients, or motifs from various sources." (39) Morrison weaves the blues and the jazz with written text in her novelistic discourse. In so doing, this blending of orality and written text becomes an undisputed and remarkable trace of pastiche. And as D'Angelo breaks down the etymology of pastiche, he informs us that pastiche is "...derived from the Italian word pasticcia, originally "a hedgepodge of meat, vegetables, eggs, and a variety of other possible additions."(40) Through D'Angelo's etymological definition of pastiche, we can call Morrison's narrative, a pastiched diasporic novel because her poetics of intertextuality covers not only a wide range of 
intertextuality strategies, but also it references to some aspects of African culture and tradition. For example in Beloved, Shango, the Yoruba god of iron is referrenced. It is this West African collective worldview permeating Morrison's text that Henry Louis Gates and Jennings call respectively "signifying" and "African retention". Gates defines "signifying" in The Signifying Monkey as a metaphor for African cultures that have crossed and survived the Middle Passage and as synecdoche for Africa. Gates's definition of "signifying" dovetails and overlaps with Jennings's definition of "African retention".

Because of the wide scope of intertextuality that the writing of Morrison covers, we can see that her fiction is animated by a web of signifying. Hence, insofar as we can grasp that web of signifying, we can better understand her message. In other words, she wants her reader to be not only a critic but also an intertextual and cultural critic. And the intertextual critic endeavors to deconstruct the different bits and pieces that Morrison uses to sew her narrative; and the cultural critic tries to identify the African cultural references that Morrison draws on. For example, Roland Barthes, in $S / Z$, declares that there is not a single text that can be said to be new since there is always a latent or manifest intertextuality in a narrative. He further explains that any text refers to other texts upon which it relies for meaning and significance. To illustrate his point, Barthes writes: "the 'I' which approaches the text is already itself a plurality of other texts, of codes which are infinite." (10)

Gerard Genette's work on intertextuality is also very relevant in this paper. In his work Palimpsestes: La littérature au second degré, Genette, like D'Angelo, talks about the different forms of intertextuality. He points out the following ones: hypertextuality, paratextuality, metatextuality, architextuality, and transtextuality. These different forms of intertextuality designate the different relationships, latent or apparent and unconscious or conscious, that a text can establish with other preceding texts. Hypertextuality, paratextuality, and transtextuality are the forms of intertextuality that are most recurrent in the work of Morrison. Genette defines hypertextuality as: « J'appelle donc hypertexte tout texte dérivé d'un texte antérieur par transformation simple (nous dirons désormais transformation tout court) ou par transformation indirecte: nous dirons imitation » (14). "I call hypertext all text derived from a previous text by a simple transformation (from hereon we will use in short the term transformation) or by indirect transformation: we will use the term imitation." (My translation). In lay terms, hypertext is any "text I" which draws a link with another "text II", the "text II" is the hypertext and the "text I" is the hypotext. The "text II" draws on "text I". Genette further argues that there is not a single text which does not draw on another text or other texts at some level. He writes: «il $n$ 'est pas d'œuvre littéraire qui, à quelque degré et selon les lectures, $n$ 'en évoque quelque autre et, en ce sens, toutes les ouvres sont hypertextuelles » (6), that is to "There is no literary work which, to some degree and according to the readings, does not evoke any other and, in this sense, all the works are hypertextual." (My translation). And the work of Morrison can be read as a grand narrative of palimpsest, and palimpsest is per sey a hypertext. Some writings of Morrison can be read as a hypertext and its hypotext is the Bible. In Song of Solomon there are different fragments of the Bible. The reader familiar with the Bible could easily put finger on these fragments. For example, Pilate is a biblical name that recalls the man who crucifixed Jesus. Beloved opens with a biblical epigraph Romans 9:25 that runs like this:

I will call them my people, which were not my people; and her Beloved, which was not beloved.

Therefore, the Bible stands for the hypertext and Beloved for the hypotext. Similarly, the african sculptures opening part I, part II, and part III of Beloved are hypertexts and the african art, particularly sculpture is the hypotext. The biblical epigraph opening Beloved can also be read as a paratext. Paratextuality, to paraphrase Genette, refers also to the relationship that a text has with its different elements (title, epigrapgh, preface, author's note). The epigraphs opening Home and Song of Solomon function then as paratexts as well.

Besides the Bible, Morrison echoes world literature, drawing on great writers like Homer to model her fiction after the image of these great writers' masterpieces. For example, in Song of Solomon not only does Morrison mold the old wise woman repository of the African American history and tradition after the image of the enchantress in Homer's Odyssey, but also she picks up the same name for her, Circe, as Joyce Irene Middleton underlines. As Odysseus was guided in finding his way home by Circe so does the Circe in Song of Solomon provide Milkman with invaluable help. First, she turns Milkman into an active listener just like Odysseus was able to grasp the hints through his conversation with Circe because he could listen with attention. The Circe in Song of Solomon says to Milkman, "you don't listen to people. Your ear is on your head, but it's not connected to your brain." (247) Each time that Morrison echoes a writer there is a clear point that is being driven home. As already mentioned,

Sy, O. (2019). Toni morrison's poetics of intertextuality or the supreme art of borrowing. International Journal of Linguistics, Literature and Culture, 5(5), 36-54. https://doi.org/10.21744/ijllc.v5n5.742 
Song of Solomon engages with classical literature (Odyssey and the Bible) and is a sort of palimpsest of classic literature through the themes of good and evil and storytelling traditions it explores.

Morrison echoes Joseph Conrad through the exploration of the conflict between good/evil and self/other in Sula. In Conrad's text where the exclusive phrase "one of us" is used, there is always a thorough clash between the "self" and the "other". And inclusiveness is only possible when one of the parties accepts the stereotypes heaped upon it and embraces its subject and subaltern status. In the context of Morrison's narrative, we can only talk about inclusiveness if the "other" surrenders to the anonymity and the limits set by the mainstream American culture, the "self". In Conrad's text structured around good/evil and self/other, there is a symmetry between darkness and light, civilization and backwardness. For the sake of illustration, we can mention Victory, Heart of Darkness, Lord Jim, Amy Foster. In all these narratives of Conrad, there is a confrontation between the self (the European) and the other (the native). In Victory, for example, Wang is not just represented as a Friday figure in Daniel Defoe's Robinson Crusoe, but he is also orientalized. He is referred to as "yellow hands" and "cardboard face" (271). Similarly in Amy Foster, the main character Yanko is referred to as "outlandish" and "castaway". The symmetry or opposition in Lord Jim and Heart of Darkness are so well discussed by scholars that they have become classic. The same pattern of symmetry of self/other and good/evil runs throughout Sula like a subdued metaphor. Sula is otherized and made epitomize evil. Overall, Morrison uses classical texts like Odyssey and Heart of Darkness or Lord Jim to frame respectively the orality in her fiction and to structure the self/other and civilization/backwardness symmetry in her text.

But Morrison also draws from the "economics of slavery" as Gates argues. Therefore, besides being an intertextual critic to decipher the inter-dialogue between the text of Morrison and world literature, the reader of Morrison's fiction needs to be a cultural critic so as to grasp and interpret the "economics of slavery" or the "signifying" in her novels. These different borrowings from world literature and "economics of slavery" question authenticity and originality and yet through these different borrowings Morrison creates a pastiched literary work that stands out as an original genre. In fact, what Morrison has accomplished here reveals a praiseworthy dimension of originality since as James E. Porter writes in his essay "Intertextuality and the Discourse Community":

Creativeness does not consist in producing new sentences. The newness of a sentence is a quite unimportant - and unascertainable - property and 'creativity' in language lies in the speaker's ability to create new meanings: to realize the potentiality of language for the indefinite extension of its resources to new contexts of situation.... our most 'creative' acts may be precisely among those that are realized through highly repetitive forms of behavior. The creative writer is the creative borrower, in other words. (37)

Drawing on Porter's assumption that "the creative writer is the creative borrower," it can be argued that Morrison is a creative writer and borrower, for she draws her inspiration from the "economics of slavery" (to use Gates' term), the African culture, and the official historiography to craft her own fiction. That is to say like the bee which touches many flowers to create something of its own so does Morrison use the same process to create something new over which she can claim authorship. Since she acts like the bee by touching different flowers to make some honey so should the reader be versatile and culturally grounded to grasp the different flowers touched. Morrison is very conscious of the power of narrative construction as she puts it in her nobel lecture: "Narrative is radical, creating us at the very moment it is being created." (4) Morrison's poetics of intertextuality is a radical narrative since it requires a reader who has to be both an intertextual and cultural critic to grasp the meaning and significance of her text. This radical narrative that calls upon the intertextual and cultural critic, Morrison presents it in her essay "Rootedness: The Ancestor as Foundation" as her "elusive but identifiable style". She writes:

I don't like to find my books condemned as bad or praised as good, when that condemnation or praise is based on other criteria from other paradigms. I would much prefer that they were dismissed or embraced on the success of their accomplishment within the culture out of which I write. I don't regard black literature as simply books written by Black people, or simply as literature that uses a certain mode of language in which you sort of drop $g$ 's. There is something very specific and very identifiable about it and it is my struggle to find that elusive but identifiable style. (342)

As we can infer from this quotation, not all readers can read and make sense of Morrison's text. Her narrative addresses the acute reader, meaning the cultural and intertextual critic, who can find that "elusive but identifiable style." And I would slightly disagree here with Morrison that style which her acute reader must be armed with to penetrate her text is not "elusive." It is there palpable; however only the reader who is conversant with the African culture and the "economics of slavery" out of which Morrison's fiction emerges can dive deeper into the inner meaning of her narrative. Also, Morrison's preceding quotation teaches us that to approach her narrative with only the western literary criticism 
is to make a shallow reading of her fiction. Sticking to western literary criticism to analyze Morrison's narrative, as is often the case, lends itself readily to a sort of Eurocentricism. In other words, to accept that the western literary criticism is the sole valid approach to Morrison's fiction is to reckon and erect as a hegemon that literary approach. This means that any Afrocentric approach, as Jennings and Henry Louis Gates do, is invalid. And as I reread Morrison's quotation that is what she alludes to by this sentence: "I would much prefer that they were dismissed or embraced on the success of their accomplishment within the culture out of which I write."

The preceding quotation implies that the notion of culture and community are central in Morrison's writing. For example, her poetics of intertextuality shows that the writer is not an island onto himself or herself. He or she is not an independent and separated self from the community for whom he or she intends to be a mouthpiece. In fact, Morrison's poetics of intertextuality by and large stresses the connection between the community for whom she writes and the cultural heritage she gets her inspiration and narrative tools from. Porter highlights this new role that the rhetoric of intertextuality in contemporary novelistic discourse vests on the writer:

By identifying and stressing the intertextual nature of discourse, however, we shift our attention away from the writer as individual and focus more on the sources and social contexts from which the writer's discourse arises. According to this view, authorial intention is less significant than social context; the writer is simply a part of a discourse tradition, a member of a team, and a participant in a community of discourse that creates its own collective meaning. (33-34)

To comment on Porter's assertion, we can make the point that he assigns to the writer a new social responsibility: much of his or her craft has to come out of his or her culture and he or she has to contribute to the narrative of the community by voicing out their concerns. When we apply this principle to Morrison, it clarifies why she invites her reader to find that intertextual nature of discourse underlying her fiction she calls her "elusive but identifiable style."

Another accomplishment in Morrison's poetics of intertextuality that is part of her "elusive but identifiable style" is the Testimonio aspect of her narrative. True, there is an aestheticization of violence or trauma. The textualized bodies of some characters function as intertext upon which Morrison inscribes the unspeakable trauma of slavery. The textualized bodies fall into the category of the testimonio genre. A testimonio is a genre that provides space for the telling of experienced memories or lived experiences manifested often through scars and signs written on the body parts of the victims. George Yudice identifies it as the adequate genre for the oppressed and the marginal. In his essay "Testimonio and Postmodernism," Yudice defines the major features of testimonio in contrast with postmodernism in these terms:

Testimonial writing shares several features with what is currently called postmodernity: the rejection of master discourses or prevailing frameworks of interpreting the world and the increasing importance of the marginal. However, there are significant differences in the ways in which "hegemonic" postmodern texts and testimonial writing approach this emergent fragmentation and marginality. Even though one of the projects of certain postmodern texts is to dismantle the classics of Western tradition, their purview remains, unsurprisingly, Western. (21)

As Yudice highlights in his assertion, testimonio is a narrative that endeavors to put the marginal at the centre, and at the same time it disputes 'hegemonic' discourses. In Morrison's fiction, the hegemonic discourse is the mainstream American culture and the historiography. Morrison puts the vernacular (blues and jazz) which is considered as a discourse of the periphery at the center of her poetics of intertextuality, in so doing, she " ...decenters and deforms literary language, making it appropriate for telling a blue, Black/tale" (161) as Alan J. Rice argues. And Morrison, to further dismantle the foundations of Western literary tradition, defines her novel, Jazz, as a jazz gesture that is to say the text has to function like jazz without being jazz per sey. Sula is also driven by a jazz stream. By incorporating the blues and the jazz in her poetics of intertextuality, Morrison not only draws from the community heritage and tradition, but also she dismantles the novelistic norms.

Morrison's poetics of intertextuality rejects linearity, chronology, and coherence to mimic the riffs and evanescence of jazz and blues. As she puts it in her nobel lecture, "the vitality of language lies in its ability to limn the actual, imagined and possible lives of its speakers, readers, writers." (3) Therefore, to limn the Middle Passage and the experience of displacement of the slaves from one plantation to another, Morrison uses the riffs of the blues and jazz to render this reality. Riffs are repetitious rhythmic figures that enable"... the musician to structure improvisations with reference to what has already been created" (170) as Alan J. Rice explains. And the evanescence dimension of jazz allows Morrison to work against all temporality and chronology. The evanescence dimension of jazz makes the

Sy, O. (2019). Toni morrison's poetics of intertextuality or the supreme art of borrowing. International Journal of Linguistics, Literature and Culture, 5(5), 36-54. https://doi.org/10.21744/ijllc.v5n5.742 
narrative of Morrison fluid and recursive, it moves easily back and forth through time; and the riffs are meant to better fictionalize the boomerang experience of blacks in America. Rice, in analyzing the evanescence of jazz in Morrison's text claims that evanescence is a bridge through which the characters of Morrison pass by in their search for remembrance or rememory. Rice writes:

Morrison uses this combination of the diachronic and synchronic in her novels where characters in long oral narratives, happening in the present, have an easy facility to jump backwards in time to fill in gaps and provide explanations. They remember the past through improvisatory riffs situated in here and now. Obviously, such powerful expression is key for Morrison in preserving and articulating histories, the values of which have been undermined by their being largely confined to an oral mode devalued in our literate culture. (172)

Evanescence and riffs which are acknowledged music devices are transposed into the novel discourse. Thereby, Morrison appropriates and adapts the jazz and blues. Evanescence and riffs are among the elusive and identifiable blackness that Morrison invites her reader to search for in her narrative. To allow "background" stories to interrupt or intermingle with present stories, Morrison has to weave her fiction with riffs and evanescence. In so doing, through the blues and the jazz, Morrison constructs a transgressive poetics of intertextuality.

Morrison's poetics of intertextuality draws on the absurdist genre. Sula stands between genres, it is an absurdist fiction and a testimonio. Morrison combines these different genres to write down the various experiences of slavery and its sequels in her community. There is something uncanny about Sula's return to Bottom. Much the same is true with Beloved's return to her family. The world of Bottom is grotesque. There is no faith, logic or affection binding the community together. Instead the community of Bottom is torn apart because most characters feel purposeless. In this respect, Sula bears features of an absurdist fiction like Franz Kafka and Albert Camus's fiction. The main characters in Sula lack morality and purpose like Camus's Meursault in The Stranger. In his essay "The Absurd in Literature," Gregory Byala explains that the absurd can refer to a purposelessness, a negation of oneself and the world around. He writes: "The absurd, then, is born of nihilism, out of existentialism, fuelled by the certainty of death (anxiety, dread, and death being the scourge of the existentialists)." (299) The same nihilism and dread that characterize the absurd haunt Bottom. Violence is the only medium or language of communication and death is the sole activity that gets the community together. The whole people of Bottom can be looked at as the 'absurd', yet Sula is the epitome of the absurd, meaning no rationale accounts for her actions. Her actions are too uncanny. She is portrayed as the evil ripping apart Bottom; she bothers her community without any particular motive. Deborah Guth mentions the sequence of destructions that Sula has caused for her community in this passage:

She destroys her friend's marriage without fore- or afterthought and without really desiring Jude. She has her grandmother placed in an old-age home simply because she does not want her in the house; even sex gives her none of the deep satisfaction it gave to her sensual mother. Her final conversation with Nel is a model of contemptuous disrelation... (557)

Sula lacks something vital which she doesn't know let alone articulate. The narrator informs us that "there is something newly missing" (52) in Sula, adding further down in the narration that she is "... distinctly different" (102). Sula is strange and outlandish since she is not whole. She is a social misfit who can communicate only through violence. She herself is not safe from her own absurd deeds. She cuts her finger off. This language of violence which reaches its peak through Sula's self-mutilation reveals the deep trauma that Sula is suffering from. Through Sula's self-mutilation, Morrison underscores the absurdity of existence in Bottom. Sula mutilates herself through a fight with Nel, her husband. Her Grandmother, Eva Peace, has her leg run over by a train when she was trying to provide for her family. Therefore, Sula's madness, like that of Bottom, is driven by both internal and external forces. She is not only the epitome of evil but also she exemplifies the idea that evil can be passed on. Sula, like Eva Peace, is a murderer. She let Chicken Little drown in the river and her Grandmother killed her son Plum. The self-mutilation of Sula and the murders the characters commit illustrate that Sula is not only an absurdist piece of fiction, but also a testimonio genre where upon the body of the characters are inscribed the violence and the trauma. At times the violence is so intense that instead of simply letting itself inscribed on the body of the victim, it ends up killing the latter. Patricia Mckee, in her essay "Spacing and Placing Experience in Toni Morrison's Sula," describes Sula and her complex relation to Bottom in these terms:

In Sula, people in the Bottom amass an identity of evil called Sula that functions somewhat like the "background" of racism Morrison identifies in white American literature. But the need for such ground, and its effects, is different. One might say there is a projection of evil within the black community useful to withstanding the projections 
practiced upon the community by whites. Under pressure from external forces of racism, people in the Bottom distribute their moral variations among themselves in order to contain what they could project into the white population only at the risk of their own lives. What they contain is not only the evil that would more accurately be located outside their community but their own rage, which because limitless, cannot be stopped once let loose. (59)

Drawing on Patricia Mckee's quotation, a possible reading of the drama unfolding in Bottom is the idea that if you isolate a community, putting them in an inhumane and animal-like habitat they will end up behaving like animals. In other words, Morrison is saying that if you reduce a people to one thing over time they will become that thing.

Sula is the escape goat of her community and the personification of an outside racism that paradoxically can neither be fought back nor self-contained. Yet despite the fact that the evil of Bottom is heaped upon Sula, there is in the other characters a want or desire repressed or unfulfilled. And it is the "evils of racism practiced by white people," as Patricia Mckee argues, which causes this repressed want. Patricia's point speaks to Alan Nadel's assertion that "By the time that segregation had fully replaced slavery, therefore, the restraints had become internalized and demanded silence and invisibility." (14) Therefore, we can read the train that run over Eva Peace's leg as the mainstream society or the new forces of segregation. The train stands for modernity, progress, and development, and yet instead of pulling the townspeople of Bottom out of poverty, it rather leaves them behind and oppresses them. When Eva Peace decides to go out so she could earn a living to provide for her children, she expresses her will and desire to get out of poverty and be part of the mainstream society, the visible society which is in economic and social progress, yet the train has shattered her dreams. Hence, she is condemned to stay forever in Bottom.

Bottom, as its name suggests, refers to a city where invisible people who are left behind by the train of progress and modernity dwell. Bottom is at the bottom of the economic ladder, which results in bad parenting and unhappy marriages. The train that cut off Eva Peace's leg recalls the prison gate keeper in Michael Foucault's Madness and Civilization. Eva Peace as the incarcerated other has to remain invisible. Bottom is the institution of unreason, the prison which she does not have to trespass. Alan Nadel in Invisible Criticism shows how Foucault's theory of imprisonment in Madness and Civilization can help us better understand the segregation of blacks after slavery. This passage where he quotes Foucault to illustrate how the discipline of the asylum works on the madman relates aptly to the situation of Eva Peace and the rest of Bottom:

... fear no longer reigned on the other side of the prison gates, it now reigned under the seals of conscience... The asylum no longer punished the madman's guilt, it is true, but it did more, it organized that guilt; it organized it for the madman as a consciousness of himself, and as a non-reciprocal relation to his keeper; it organized it for the man of reason as an awareness of the Other, a therapeutic intervention in the madman's existence. In other words, by this guilt the madman became an object of punishment, always vulnerable to himself and the Other. (14-15)

This quotation which Nadel selected from Foucault sheds light on the inner violence and absurd existence within Bottom. The conscience of the Bottom community is imprisoned; therefore they are psychologically weak and vulnerable. The symbolism of the train as the prison gate keeper illustrates that the world upper or around Bottom negates Bottom and refuses to see it as part of the nation, and most of all hems in the life of the Bottom people. Drawing on Nadel's remark, Bottom is 'an organized guilt' permanently subject to punishment and vulnerable to itself and to mainstream society. The few people of Bottom who ask for recognition and visibility are punished like Foucault's madman. Foucault and Nadel's description of the restrictions imposed upon the segregated other recalls the system of panopticon and surveillance prevailing in America today that Ruth Wilson Gilmore and Graig Gilmore in Policing the Planet portray. In this respect, they write: "The modern police system was designed to keep the marginalized in their place and to warn the poor of a fate worse than poverty" (173). Reading Sula in the light of Policing the Planet illustrates that the past is irrationally linked to the present and as William Faulker says « the past is never dead. It's not even past » in his piece Requiem for a Nun. To Morrison then, history is never linear but always cyclical, which means that the invisible minority of Morrison's community lives now in a post-panoptic society. The recent police violence against Blacks in Baton Rouge, Houston, Dallas, Cleveland, Ferguson, and New York, and the racial riots that they have engendered are examples of this post-panoptic society. The repressed want or unfulfilled desire in Eva Peace and Sula result from this panopticon and imprisonment. The famous saying of Bottom that "The only way to avoid the Hand of God is to get in it "(56) is an invitation for self-awareness and perseverance. The people of Bottom are conscious of their incarceration but there is nothing much that they can do. The institution of unreason is too powerful that it engulfs them like the train which swallows Eva Peace's leg.

Overall, through the self-mutilation of Sula and the repressed yearning of the townspeople of Bottom, which results in uncanny and absurd actions, Morrison creates a narrative that is both an absurdist and a testimonio fiction. Morrison

Sy, O. (2019). Toni morrison's poetics of intertextuality or the supreme art of borrowing. International Journal of Linguistics, Literature and Culture, 5(5), 36-54. https://doi.org/10.21744/ijllc.v5n5.742 
weaves these different genres in her poetics of intertextuality, for the experience of her community she tries to write down is so various that it stands between genres. In other words, Sula stands between genres much like Beloved, Jazz, and Song of Solomon. For example, Beloved, Sula, and Song of Solomon are magic realistic novels too.

Beloved and Sula are magic realistic stories. Magic realism allows for Morrison to blend uncanny or irrational elements with her fiction. Magic realism is defined by Allen B. Ruch and Tamara Kaye Sellman, in "Magical Realism: The way my grandmother used to tell stories" in the online magazine Margin, quoting M.H. Abrams' A Glossary of Literary Terms, 6th ed., as:

\begin{abstract}
The term magic realism, originally applied in the 1920s to a school of painters, is used to describe the prose fiction of Jorge Luis Borges in Argentina, as well as the work of writers such as Gabriel García Márquez in Colombia, Gunter Grass in Germany, and John Fowles in England. These writers interweave, in an ever-shifting pattern, a sharply etched realism in representing ordinary events and descriptive details together with fantastic and dreamlike elements, as well as with materials derived from myth and fairy tales. Robert Scholes has popularized metafiction as an overall term for the large and growing class of novels which depart drastically from the traditional categories either of realism or romance, and also the term fabulation for the current mode of free-wheeling narrative invention. These novels violate, in various ways, standard novelistic expectations by drastic -- and sometimes highly effective -- experiments with subject matter, form, style, temporal sequence, and fusions of the everyday, the fantastic, the mythical, and the nightmarish, in renderings that blur traditional distinctions between what is serious or trivial, horrible or ludicrous, tragic or comic.
\end{abstract}

Sula and Beloved's returns to their respective communities and the possibility of characters to fly out of slavery in Song of Solomon have the fantastic, the mythical, and the nightmarish elements that characterize magic realism. Indeed, even the past that dogs and lingers into the present reveals a dimension of magic realism. There is in Morrison's fiction, in particular Beloved and Sula, the need to find a sort of grey area between the past and the present where the past can delve into the present without any harm. Guth sums up this dilemma that the Sweethome plantation is faced with in these terms:

Beloved, Morrison's most complex fictional achievement to date, presents yet another construction of the relation of present and past. Crafted as a fable of dynamics of memory, it dramatizes the intersection of two warring impulses towards the past, the imperative to remember and the desperate need to forget, and encodes them in a tale where one woman's attempt to defy forget and to the encroachment of the past culminates in a truly symbiotic bond between the present, imagined as haunted mother, and the past, represented in the form of her murdered and resurrected child. (584-585)

The other function that magic realism plays in Morrison's fiction is that it allows her to subvert the American historiography. In their co-written essay, "Magic (al) Realism as Postcolonial Devise in Toni Morrison's Beloved," Jamali and Razmi articulate that Beloved can be read as a postcolonial narrative. They explain that magic realism is " $a$ way to discuss alternative approaches to reality to that of Western philosophy, expressed in many postcolonial and non-Western works of contemporary fiction." (111) As a writer who speaks for the subaltern and writes from the periphery, Morrison's work can indeed be looked as a postcolonial narrative. In other words, as postcolonial fiction attempts to subvert an authoritative and self-centered colonial discourse which has undermined their culture and language so is Morrison's narrative undertaking a similar project. In her essay, Playing in the Dark, Morrison explains how black literature is viewed as non-canonical. She says:

There seems to be a more or less tacit agreement among literary scholars that, because American literature has been clearly the preserve of white male views, genius, and power, those views, genius, and power are without relationship to and removed from the overwhelming presence of black people in the United States. This agreement is made about a population that preceded every American writer of renown and was, I have come to believe one of the most furtively radical impinging forces on the country's literature. The contemplation of this black presence is central to any understanding of our national literature and should not be permitted to hover at the margins of the literary imagination. (63)

From Morrison's remark, we can see that like the postcolonial writers who write back to the empire so is she responding to the mainstream American culture and the canonization of American literature. And magic realism, because of all its non-logical accounts for things, goes hand in hand with the vernacular discourse with which Morrison mixes her novelistic discourse to counteract the hegemonic discourse of the historiography. In this respect, Morrison's fiction can be read as "postcolonial historiographic intervention"(112) as Jamali and Razmi articulate. 
Magic realism is, then, a discourse that is set against mainstream narrative, and at the same time it is a medium through which Morrison can render experiences that transcend language. For example, in Beloved there are several passages that make explicit references to the Middle Passage like this one:

I am always crouching the man on my face is dead...in the beginning the women are away from the men and the men are away from the women storms rock us and mix the men into the women and the women into the men that is when I begin to be on the back of the man for a long time I see only his neck and his wide shoulders above me... he locks his eyes and dies on my face...the others did not know that he is dead. (211-212)

This excerpt through which Beloved gives an account of the Middle Passage in her internal monologue can't be rendered through a rational and logical discourse. And much the same is true with Jake's childhood appeal to his father, Solomon, not to leave him behind when he flies back to Africa in Song of Solomon. These different experiences trump the logic and rationality of any codified language. This shift and blurring of places, realities, and boundaries is what Jamali and Razmi, quoting Wendi B. Faris, refer to as "defocalization." They define "defocalization" as:

In magical realism, the focalization - the perspective from which events are presented- is indeterminate; the kinds of perceptions it presents are indefinable and the origins of those perceptions are unlocatable. That indeterminacy results from the fact that magical realism includes two conflicting kinds of perception that perceive two different kinds of event: magical events and images not normally reported to the reader of realistic fiction because they are not empirically verifiable, and verifiable (if not always ordinary) ones that are realism's characteristic domain. Thus magical realism modifies the conventions of realism based in empirical evidence, incorporating other kinds of perception. In other words, the narrative is "defocalized" because it seems to come from two radically different perspectives at once. (112)

This "defocalization" which allows Morrison to convey "two radically different perspectives at once" and uncanny facts is present in Song of Solomon, Jazz, and Home.

In Song of Solomon, Milkman tries to figure out the meaning of the "song" of Solomon throughout the text. As he travels into the country, he decodes bits and pieces of the song's meaning. The meanings of the "song" of Solomon set the hero through a mental or physical rite of passage. The bits and pieces of the "Song" of Solomon that Milkman gathers are "defocalized" since they come from different antagonistic sources: orality and written speech.

Through this "defocalization," Morrison can better write down a corrective narrative, meaning one that corrects the erasure of African American history in the historiography. And like any corrective narrative, it tends to go to the other extreme, which justifies the extreme violence and the metafiction or magic realist elements in her fiction. For example, Violet's attempt to inflict pain on the corpse of Dorcas speaks volume about this uncontrollable, uncanny, and irrational violence. The narrator relates the scandal that Violet made in the funeral ceremony in this passage:

When the woman, her name is Violet, went to the funeral to see the girl and to cut her dead face they threw her to the floor and out of the church. She ran, then, through all that snow, and when she got back to her apartment she took the birds from their cages and set them out the windows to freeze or fly, including the parrot that said, "I love you." (3)

The birds which she let freeze to death further strengthens the cold irrational violence in the narrative. In the same vein, to torture and take a revenge on her husband for cheating on her, she manages to get the picture of Dorcas and hangs it "... on the fireplace mantel in her own parlor..."(6), and she also let her boyfriend visit her in the house. I can stretch this string of cold violence further to show that Morrison's corrective narrative by dint of calling forth the effects of slavery and segregation on her community goes to the other extreme, which is underscored by the eco-narrative that further stresses the coldness of Violet.

The day that Violet made the scandal at the funeral ceremony is foretold by the falling of a thick snow. Morrison brings in an eco-narrative to make the coldness of Violet stand out. Through the eco-narrative, the snow becomes an accomplice by wiping out Violet's trace. The narrator says: "The snow she ran through was so windswept she left no footprints in it, so far a time nobody knew exactly where on Lenox Avenue she lived" (4). The snow conceals Violet's identity. In so doing, it is not overstretched to argue that the snow is as guilty as Violet. Further down in the text, the narrator describes the City as "winterbound". The snow sets itself against the happiness of the City dwellers. It disturbs the tranquility of the City as Violet interrupted the funeral ceremony atmosphere. Like Violet, the snow is a plague, an evil, a hindrance as this passage suggests:

Sy, O. (2019). Toni morrison's poetics of intertextuality or the supreme art of borrowing. International Journal of Linguistics, Literature and Culture, 5(5), 36-54. https://doi.org/10.21744/ijllc.v5n5.742 
Eight years later, the day before Violet's misbehavior, when the snow comes it sits where it falls on Lexington and Park Avenue too, and waits for horse-drawn wagons to tamp it down when they deliver coal for the furnaces cooling down in the cellars. (10)

As the snow was tamped down to allow people to run to their businesses so is Violet dumped out of the church so the funeral ceremony can go on. The snow is like the historiography, it conceals crimes or relates them in a perfunctory way. And the thick snow that falls on the day when Violet ruins Dorcas's funeral ceremony does not just conceal the truth, it takes part in the crime. Hence, I read the snow as an embodiment of the sequels of slavery and the direct result of segregation. In other words, the snow is the modern version of the ideology of whitewash which refuses to reckon the domestic and inner city violence in the African American population as being the direct result of a "ghettoization," meaning the lack of a good policy of economic emancipation. Both Violet and Joe Trace left the country to find better living conditions in the City. Violet, the narrator tells us, is an unlicensed hair braider as this passage suggests:

Such restless nights make them sleep late, and Violet has to hurry to get a meal prepared before getting ready for her round of heads. Having a knack for it, but no supervised training, and therefore no license to do it, Violet can only charge twenty-five or fifty cents anyway, but since that business at Dorcas' funeral, many of her regular customers have found reasons to do their own hair or have a daughter heat up the irons. (13)

It is this sort of informal business that Violet runs which I call "ghettoization." She is deprived of the money to attend a professional hair braiding school and she does not have any other skill to undertake another serious business. Dorcas, Violet's victim, was also as skill limited as Violet. She was a blues singer and a sort of prostitute. Poverty, a consequence of enslavement and segregation, drives the three of them (Dorcas, Joe, and Violet) to the City. And the City doesn't offer them much than sex and trivial jobs. If in Beloved, the slaves of Sweethome are moved around by their owner, in Jazz it is the economic pressure, the impact of "ghettoization" that makes them move from place to another in search of a better living condition. There is a latent search for home, belonging, and motherhood. This search for home is recapitulated in the characters' lack of a physical mother. Home is the place of safety, rest, and tranquility where people are nourished and entertained by their mothers or spouses. In other words, without a mother, a home people lack a vital element. All the main characters in Jazz suffer from what I might call a 'mental dislocation,' meaning they are not mentally sound. Violet is raised by a single parent: her mother, Rose Dear. Rose Dear later commits suicide. Joe is adopted; he does not have information about his mother. Dorcas is also a motherless figure; she was raised by her grandmother, True belle. Overall, in Jazz Morrison deals with the legacy of slavery more subtlety. She makes the snow stand for the ideology of whitewash and white supremacy as it wipes out the footprint of Violet to mute her crime, and the profound historic rationales underlying Dorcas's murder. Dorcas's murder like the other crimes in the text reveals an amalgamation of right and wrong, and honesty and dishonesty. The characters' sense of wrong and right is blurred. In Jazz, the characters are so poverty stricken and 'mother hollow' that their animal impulse takes over their humanity. Indeed, all the crimes that the characters commit reveal some psychological inability to love and protect. To put it differently, the line between love and hatred, honesty and dishonesty is mixed up. For example, the crime of Joe Trace is an amalgamation of right and wrong, love and hatred, honesty and dishonesty: he coldly murders his girlfriend for cheating on him while he himself cheats on his wife. It is obvious that he kills his girlfriend out of love as his deep-felt remorse suggests. But he is wronging his wife while searching for love. Similarly, Dorcas in her quest for love wrongs Joe Trace. Each and every one of these characters' sense of justice and injustice, love and hatred is flipped around. Joe Trace does not realize that he killed Dorcas for committing the same sin that he indulges in. Violet's sense of love and hatred is more turned upside down. To win the cheating match so to speak, she goes to the extreme by welcoming her boyfriend into the house with her husband's awareness, and brings the picture of Dorcas into the house to make her husband suffer, but paradoxically, she ends up falling in love with the picture. This confusion between wrong and right, justice and injustice, and the fact that Morrison flips around these crustal clear notions to make one stand for the other in the perception of the characters can be understood only through the realm of magic realism where another set of logic and paradigm operates like defocalization. Through defocalization, Morrison can write easily and eloquently about antagonistic, bundled up and flipped around realities, and troubled psyches as Razmi and Jamali in "Magic (al) Realism as Postcolonial Devise in Toni Morrison's Beloved" point out, "The reader can notice a conflict between the freed body and the enslaved psyche of the ex-slave in Beloved." (116) This antagonism between the "freed body and enslaved psyche" or troubled psyche describes the misbehavior of the characters in Jazz. A troubled psyche can't have a normal perception of reality because everything is turned upside down in his mind. Magic realism is one of the adequate tools that Morrison is equipped with to limn these troubled psyches. Morrison 
weaves then her poetics of intertextuality with magic realism to render to its fullest the effects of segregation on her community (Middleton, 1993; Morrison, 1984; 2007; 1977; 2012; 2007; 1984; 2004).

Home and Jazz are also built through a defocalization pattern. In Home, like in Jazz, there are multi-layered truths, viewpoints, and narrations. In Home, the interplay between the multiple narrating voices (in both first and third person), and focalizing views (through the third person voice) make reading Morrison's text challenging. There are, for example, changes of views and focalizations in the very same passages. And at times a narrator questions his or her own assumptions. This particular narrative structure brings up the intricate issue of reliability. Are these different narrators and their contradictory stories reliable? Any reader familiar with narrative techniques would argue that these stories are true and reliable. Morrison picks up such a narrative structure to simply blur the line between truth and falsehood. For example, by the end of the novel, Frank Money through his first person point of view changes his mind along the story. Laura Castor reads this unreliability of Frank Money’s narration in this passage:

Although he (Frank Money) admits to "lying" both to Morrison and the reader, and to himself, we don't know for sure whether it is only at this point that he can recognize his "lies" or whether he deliberately misled himself and us (Morrison, Home 133). These possibilities also suggest that some of what the third person narrator has relayed may be equally unreliable. (142)

I read the unreliability of Frank Money's narration as an invitation for Morrison to the reader to know how a truth can be deconstructed to become an overt lie and vice versa. Also, for a narrator like Frank Money who suffers from a postwar trauma and disillusionment, the reader can easily understand why Frank Money is not so balanced to narrate a linear, reliable, coherent, and simple narrative. His narrative is defocalized, going in every direction with conflicting evidence at times. In other words, his narration mimics his psyche. Frank Money's psyche is in conflict with itself like the conflicting freed body and the enslaved psyche of the ex-slave in Beloved. Frank Money served his country in an integrated army, and yet when he comes back home he feels discriminated and segregated. Like someone falling from grace to grace, Frank Money's bitter disillusionment effects his memory. Pierre Nora's theory of "lieux de mémoire" can help us better understand what is happening in the brain of Frank Money to the point that he has lost his aptitude to reconstitute the different elements of his history. Nora argues that "lieux de mémoire" (or sites of memory) occurs when the individual crystallizes and stores his different experiences, creating a historical continuity between his past experiences and his present life. (7) In other words, "lieux de mémoire" is a spontaneous memory. Frank Money has lost his "lieux de mémoire" so his unreliable narration in which he doubts himself is an attempt to both retrieve and create a lost memory or "lieux de mémoire". But as evidenced through his defocalized narration, coherence or chronology and Frank Money's psyche are clear to the point of incompatibility.

A third interpretation of the multi-layered view or narration in Home is that Morrison tries to engage with the reader as Laura Castor points out:

As readers we actively participate in her characters' healing through the multiple voices of her narrators. Through Morrison's shifts in narrative perspective, we enter imaginatively into "the social" arena where the novel's cultural work takes shape. In many parts of the text we hear Morrison as omniscient third person storyteller who confidently assumes the ability to focalize events through the shifting perspectives and priorities of characters in various places and times. We hear the narrating first person voice of Frank who, at regular intervals, seems to talk back to the third person narrator to reveal a different version of the Frank she narrates. Toward the end of the novel, Frank's first person narrator seems to change his mind about parts of his story. (142)

As we read through Laura Castor's quotation, we can infer that Morrison uses such a narration with conflated and superimposed voices and viewpoints because she wants to bring to the fore how the history of her community has been either partially told or flipped around to the point that it is hard to sift through and piece together the different parts of their history. Maybe, it is because of this conflation or superimposition of versions of histories that many histories of African Americans are not archived. Another reading of these various perspectives is that there are many truths hidden or unhidden in African American history all of which can't be rendered through one perspective. Even though these perspectives complement or contradict each other, they all engage with the archives. These conflated and superimposed histories/stories account for the pluri-meaning or polyphonic aspect of Morrison's poetics of intertextuality.

These multiple perspectives and views which engage each other, contradicting or complementing each other in Morrison's fiction, recall one aspect of "trauma literature". Indeed, Morrison's poetics of intertextuality draws greatly on “trauma literature”. In her essay “Entanglements of Trauma: Relationality and Toni Morrison's Home”, Irene Visser defines some features of what she terms "postcolonial trauma studies." First, she argues that the writings of Morrison

Sy, O. (2019). Toni morrison's poetics of intertextuality or the supreme art of borrowing. International Journal of Linguistics, Literature and Culture, 5(5), 36-54. https://doi.org/10.21744/ijllc.v5n5.742 
can be read as a postcolonial literature since it denounces a system of colonialism from within. Quoting Sharon Rose Wilson, Irene Visser writes:

Morrison is a postcolonial writer who "powerfully critiques U.S. colonialism of both past and present, the system of patriarchal racism, sexism, and classism that has not only denied the freedom, self-determination, and even humanity of African Americans, but has sometimes literally colonized the bodies of people who live within its territories and borders." (5-6)

Irene Visser explains that as a postcolonial trauma genre, the fiction of Morrison bears characteristics of narrative rupture and aporia; and there are "various modes of interruptions and disjunction of style, tense, and focalization, as well as compulsive repetition of telling and retelling." (6) The point of Visser that Morrison's fiction is a "postcolonialtrauma genre" has a twofold implication: as a postcolonial literature, it speaks up against a system of oppression and at the same time it highlights the trauma that the oppressive system inflicts on the victims or the colonized. Morrison sets herself against a monolithic and linear narrative since she wants to produce a narrative complex enough to render the experiences of her once enslaved and later segregated and now policed community. Morrison's poetics of intertextuality has to be transgressive since it stands up against a system and speaks unspeakable things as she articulates in her essay "Unspeakable things spoken". It is a discourse of resistance and resilience. The characteristics of trauma literature underlying her poetics of intertextuality is a discourse of resilience. Through her trauma literature, Morrison aestheticizes trauma through the scarred bodies of the characters. The scars, instead of being signs of horror, are turned into symbols of endearment that carry the loaded identity of their bearers. For example, the narrator describes Denver's desire to carry the same scar as her mother in this passage:

She picked me up and carried me behind the smokehouse. Back there she opened up her dress front and lifted her breast and pointed under it. Right on her rib was a circle and a cross burnt right in the skin. She said, 'This is your ma'am. This,' and she pointed. 'I am the only one got this mark now. The rest dead. If something happens to me and you can't tell me by the my face, you can know me by this mark.' Scared me so. All I could think of was how important this was and how I needed to have something important to say back, but I couldn't think of anything so I just said what I thought. 'Yes, Ma'am,' I said. 'But how will you know? How will you know me? Mark me, too,' I said. (72)

Further down in the text, Sethe explains how she was inflicted her chokecherry tree mark by Mr. Buddy. The passage runs like this:

It's a tree, Lu. A chokeberry tree. See, here's the trunk - it's red and split wide open, full of sap, and this here's the parting for the branches. You got a mighty lot if branches. Leaves, too, look like, and the dern if these ain't blossoms. Tiny little cherry blossoms, just as white. Your back got a whole tree on it. In bloom. What God have in mind, I wonder. I had some whippings, but I don't remember nothing like this. Mr. Buddy has a right evil hand too. Whip you for looking at him straight. Sure would. I look right at him one time and he hauled off and threw the poker at me. Guess he knew what I was thinking. ( 93)

These different marks/scars on the body parts of the characters like the African sculptures opening the different parts of Beloved are powerful narrative devices. Indeed, Morrison's poetics of intertextuality forces us to read and interpret a text not only with our cognitive knowledge but also with our culture. This cultural reading is necessary to grasp the inscribed scars and African sculptures functioning as paratext in Morrison's writing. These African retentions represent a great bulk of Morrison's art of borrowing. Morrison's art of borrowing implies that reading as well as interpreting a piece of fiction is more than just an attempt to engage with and communicate with the text since this engagement and communication with the text calls also on the culture of the reader. James Phelan defines eloquently reading and interpretation in the following two passages:

Reading is the act of taking in, responding, and seeking to make sense of the text, as we follow its sequence from beginning to end. In reading, we are strikingly, both passive and active, as the text acts upon us and we act upon it; the text calls upon - and we respond with - our cognitive, emotive, psychological, social, and ethical selves (though of course different texts will engage some of these selves more fully than others). When I speak of "experiencing the text," I refer to this two-sided, multidimensional, multileveled activity. Furthermore, because reading is active as well as passive, the shape it takes for any one text will depend on many things, including our individual subjectivities and the assumptions about reading that we bring to the text. (227) 
Interpretation is the act of formulating a cognitive understanding of the text. The sense-making that we do as part of reading is one kind of interpretation, and thus, strictly speaking, reading and interpretation are so closely related that they are not wholly separable. In standard academic interpretation (SAI), however, this act of formulating a cognitive understanding is systematized and presented in formal, often highly abstract language - and in that systematizing a gap frequently develops between critics' reading experiences and their interpretations...To do SAI is explain as coherently and comprehensively as possible the how and why of a text's signification. Because SAI has as its goal cognitive explanation, it involves a kind of translation. The text's language is viewed as that which is in need of explanation; the interpreter provides some other context and some other language - in effect, a code to achieve that explanation. (228)

In the light of these two quotations, we can see that there is not a confrontational relation between reading and interpretation. But Morrison's poetics of intertextuality requires that when doing SAI, we let some room for our cultural reading, what I might call a "cultural cognitive reading". This "cultural cognitive reading" is necessary to understand, for example, how the magic realism operates and how the scars are aestheticized and used as a meaningful vehicle of identity. Without this "cultural cognitive reading", the significance of Morrison's fiction is flattened. Not only is Morrison's narrative often superimposed but also there is a conflation and superimposition of genres. Only a "cultural cognitive reading" can undo these conflated traditions and genres.

Morrison's trauma literature is, for instance, mixed with magic realism. The magic realism allows Morrison to reimagine and reinvent the history of her community with all its tribulations and absurdities. In her essay "The Question of the Other: Cultural Critiques of Magical Realism," Wendy B. Faris defines magic realism as "an alternative to European realism" (103) because she articulates that:

For whatever a realist text may say, the fact that realism purports to give an accurate picture of the world, based in fidelity to empirical evidence, and that it is a European import, have led to its being experienced by writers in colonized societies like Harris's as language of the colonizer. From this perspective, to adopt magical realism, with its irreducible elements that question that dominant discourse, constitutes a kind of liberating poetics. (103)

Drawing on Wendy Faris's definition of magic realism as a poetics of liberation, we can better understand why magic realism instead of being just a literary device functions as a political weapon through which Morrison explicates the unexplainable events of history. In other words, magic realism becomes a weapon through which she carves within the historiography some space for the wounded histories of her community. The murder of Dorcas and the mental crisis that her murderer experiences after the crime, and Violet's wanton cruelty to desanctify the funeral ceremony of Dorcas and later falls in love with Dorcas' picture are examples that fall out of the realm of realism and logic. Much the same is true in Home with Frank Money who suffers from such a severe post-war trauma that he has lost his "lieux de mémoire". Moreover the experiments done on the bodies of characters in Home are also uncanny instances that fall into the category of magic realism.

Another example of magic realism in Jazz is Dorcas's picture that Violet brings home. Beyond the picture, it is the idea of the dead coming back to haunt the living which is emphasized like Beloved. The return of Beloved physically and mentally upsets her family so is Dorcas's presence (through her picture) as unsettling as the past that it reminds of. Beloved intrusively comes back into the life of her family while Dorcas is invited into the house of Joe Trace by his wife. Despite this slight difference, both Beloved and Dorcas are memories of a painful history. The first one is the embodiment of the memory of slavery, a call against national amnesia, and the second one, rather than being simply the representation of adultery, is the embodiment of psychologically unbalanced people. And this psychological disturbance can be seen as the sequels of slavery, which means that a trauma is always passed on to the children and grandchildren. This is what Marianne Hirsch theorizes as "postmemory". As she articulates, "postmemory" implies an inter- and trans- generational transmission of traumatic knowledge and experience. "Postmemory" negates the critical distance between the victims of a trauma and their heirs (children and grandchildren), which suggests that there is a profound and troubling continuity of experience between the victims of a trauma and their heirs, what Hirsch calls "received memory" (106). This oscillation between rupture and continuity and uniterrupted continuity of trauma is better conveyed through the magic realism. Then, magic realism is a genre that negates temporal and spatial delineations. In this respect Beloved, standing between two worlds can leave fingerprint on the food and make weird sounds on the roof to disquiet her mother and sisters. Similarly, Dorcas's picture not only does it stand for uncanniness and absurdity, but also it implies reincarnation. The picture has the same uncanny impact on both Joe and Violet. I can cite at some length to illustrate the similar effect that Dorcas's picture has in both Joe and Violet:

Sy, O. (2019). Toni morrison's poetics of intertextuality or the supreme art of borrowing. International Journal of Linguistics, Literature and Culture, 5(5), 36-54. https://doi.org/10.21744/ijllc.v5n5.742 
Violet agrees that it must be so; not only is she losing Joe to a dead girl, but she wonders if she isn't falling in love with her. When she isn't trying to humiliate Joe, she is admiring the dead girl's hair; when she isn't cursing Joe with brand-new cuss words, she is having whispered conversations with the corpse in her head; when she isn't worrying about his loss of appetite, his insomnia, she wonders what colors were Dorcas's eyes. Her aunt had said brown; the beauticians said black but Violet had never seen a light-skinned person with coal-black eyes. One thing, for sure, she needed her ends cut. In the photograph and from what Violet could remember from the coffin, the girl needed her ends cut. Hair that long gets fraggely easy. Just a quarter-inch trim would do wonders, Dorcas. Dorcas. (15)

As the narrator relates it in this passage, Violet has an uncanny reaction to the picture, she hates and at the same time she likes it. Her admiration toward the picture even trumps her feelings of hatred and revenge. And on the other hand, she is as troubled by the picture of Dorcas as her husband. The sentiment that Joe and Violet have toward the picture of Dorcas implies that a crime is always burdensome on both the perpetrator and the bystander. Dorcas's picture is the embodiment of "postmemory", a trauma that effects both the psyche of the victim and the perpetrator. Violet unearths the past by bringing in Dorcas's picture, and yet she ends up feeling as guilty as her murderer husband. As Morrison makes Violet feel bad about bringing up the past so does she make Dorcas's Aunt want to bury the murder of her niece because she thinks Joe's remorse is enough of an ordeal and punishment:

There was never anybody to prosecute him (Joe) because nobody actually saw him do it, and the dead girl's aunt didn't want to throw money to helpless lawyers or laughing cops when she knew the expense wouldn't improve anything. Besides, she found out that the man who killed her niece cried all day and for him and for Violet that is as bad as jail. (4)

Morrison puts into play different people: victims, perpetrators, and bystanders to stress not only the problematic of history writing but also the various sentiments that people may have about heinous crimes like Dorcas's murder of her girlfriend and his wife's attempt to desanctify a funeral ceremony. Also, the intention of Dorcas's aunt not to prosecute Joe recalls Sethe's efforts to repress the past. Indeed, as Morrison's narrator writes, "To Sethe the future was a matter of keeping the past at bay," (51) since Sethe tries to repress or kill the past which keeps coming up. Similarly in Jazz, the decision of Dorcas's aunt to mute the murder of her niece and Dorcas's picture raise the question about which stand to have toward the past. Should the past be embraced with all its ugliness and challenges? Or should the past simply be stifled as Dorcas's Aunt does? If Dorcas's aunt can easily let go the past, such is not the case with the main characters. For example, the picture of Dorcas represents the stubborn past which cannot be tamed. As Joe and Violet engage with the picture so the past dogs the present.

And as Razmi and Jamali point out, the name Sethe echoes the name "Lethe, the mystical river of forgetfulness." (116) Yet, the reader can easily realize that Sethe, whether Morrison derives her name from Lethe or not is a reversed mystical river of forgetfulness. Instead, Sethe is an anti-amnesia mystical river. Dorcas's picture is also an anti-amnesia warning, it is a "postmemory". Joe and Violet have restless nights since they can't resist the call to wake up in the midst of the night so as to engage with the picture. The narrator describes the interaction that Joe and Violet have with the picture in this passage:

And a dead girl's face has become a necessary thing for their nights. They each take turns to throw off the bedcovers, rise up from the sagging mattress and tiptoe over cold linoleum into the parlor to gaze at what seems like the only living presence in the house: the photograph of a bold, unsmiling girl staring from mantelpiece. If the tiptoer is Joe Trace, driven by loneliness from his wife's side, then the face stares at him without hope or regret and it is the absence of accusation that wakes him from his sleep hungry for her company... But if the tiptoer is Violet the photograph is not that at all. The girl's face looks greedy, haughty and very lazy. (12)

The different stands that the picture has toward Joe and Violet and the different reactions that they have in return toward the picture sum up the intricacy of history. History can apportion accusation on some, innocence on others, and it can also leave some people indifferent. The picture of Dorcas doesn't incriminate Joe (the guilty), and is indifferent to Violet. Instead of showing feelings of revenge, hatred, or accusation to Violet who ruined her funeral ceremony, the picture of Dorcas displays some pride before Violet.

Moreover the picture of Dorcas, instead of being the mere manifestation of a guilt, is a "rememory". And as such, it allows some events to stick to the memory and never go away. For example, Sethe portrays her experience as an enslaved girl as a "thought picture." (43) She says: "Where I was before I came here, that place is real. It's never going 
away...The picture is still there and what's more, if you go there - you who never was there - if you go there and stand in the place where it was, it will happen again..."(44) A picture is a tool of inscription, a medium through which one archives an event, a moment. Sethe's "thought picture" is an umbilical cord binding her to her soul. Sethe's "thought picture" and Dorcas's picture complement each other. Sethe's "thought picture" inscribes the trauma of slavery while Dorcas's picture captures the sequels of slavery on the African American community. By reducing the history of Dorcas and Violet to a picture, Morrison creates a collective memory. As Sethe says whoever goes to the place where she was enslaved can still see the picture. Similarly, Dorcas's picture as Violet and Joe wake up in the midst of the night to look at it so can the whole community engrave the picture in their mind. In other words, the pictures enable a communal reclaiming of a shared painful history. Sethe's "thought picture" recalls what Marianne Hirsch calls "communicative memory". She writes: "communicative memory is 'biographical' and 'factual' and is located within a generation of contemporaries who witness an event as adults and who can pass on their bodily and affective connection to that event to their descendants." (110) In the light of Hirsch's "communicative memory", we can argue that Dorcas's picture, Sethe's "thought picture", the plantation Sweet Home, and scarred bodies stand for communicative memories. They are all meant to archive, pass on, and institutionalize a memory. This process of institutionalization of memory is also part of Morrison's poetics of intertextuality. Memory, 'rememory', and 'postmemory' function as literary devices through which Morrison inscribes her trauma literature.

Overall, these different dimensions of "communicative memory" are aptly rendered through aspects of magic realism and trauma literature. The meaning of Sethe's "thought picture" and Dorcas's picture go outside of the framework of any linear, realistic or rational description. Through these two pictures, Morrison re-imagines and reconstitutes the unspoken truths of slavery. In this respect, Razmi and Jamali comment on the necessity to re-imagine and construct the trauma of slavery through a devise that measures up to the uncanny reality. They write:

By this re-imagination, magical realist writers, like postcolonial writers, can rewrite received historical narratives in order to challenge existing discourses of power and knowledge. Morrison is acquainted with the fact that the history of slavery of African-Americans from their own perspective has remained untold because of the oversight of dominant American and previously slave-owning culture. (116)

As Razmi and Jamali emphasize, the picture of Dorcas and Sethe's "thought picture" not only challenge existing discourses of power and knowledge, but also they subvert our understanding of rational and coherence. Dorcas's picture and Sethe's "thought picture" are predicated on epistemes that are outside of the framework of hellenistic discourse.

Another technique that Morrison's poetics of intertextuality draws on is orality. Through this orality, Morrison hybridizes the novel discourse. For example, Home opens with an epigraph which depicts a particular house. The epigraph reads: "This house is strange / Its shadows lie. / Say, tell me, why does its lock fit my key?" (epigraph, Home) There is something hostile and repellent in the house portrayed in the epigraph. And yet there is something familiar in the house. Laura Castor articulates that in the song epigraph something familiar has been turned into something alien. She writes: "Yet in the "house" of the poem, the idea of a familiar safe haven is turned into something uncannily unfamiliar." (139)

The epigraph is a song, a jazz lyric. Irene Visser in "Entanglements of Trauma: Relationality and Toni Morrison's Home" makes an interesting comment regarding the novel's epigraph. She argues that the epigraph makes us aware at the very outset that its central theme, 'home,' is to be read in relation to Morrison's previous fictional works and songs. The epigraph refers to the lyrics "Whose house is this" which are from a song cycle that Morrison wrote and that was set to music in 1992 by André Previn, long before Morrison published Home. (5) The epigraph functions, then, as a piece of music within the textual discourse. The epigraph song of Home is in dialogue with the jazz music in Jazz which can awaken memories and also turn trauma into resistance and action. The full song of Morrison from which is extracted the epigraph of Home reads like this:

"Whose house is this?

Whose night keeps out the light in here?

Say, who owns this house? It's not mine.

I dreamed another, sweeter, brighter with a view of lakes crossed in painted boats;

Of fields wide as arms open for me. This house is strange.

Its shadows lie. Say, tell me, why does its lock fit my key?"

Sy, O. (2019). Toni morrison's poetics of intertextuality or the supreme art of borrowing. International Journal of Linguistics, Literature and Culture, 5(5), 36-54. https://doi.org/10.21744/ijllc.v5n5.742 
The full text of the song shows that this song is a real blues that is better articulated through music than through a written text. Indeed, it must be emphasized that a song is but a speech set to music through a voice. Momar Cissé explained that a song is a vocal music as opposed to instrumental music and that the relationship between a song and music is very narrow. Cissé states in this regard that « Chez les Wolof d'ailleurs, il n'existe pas de terme pour dire 'musique'. Le mot «woy » qui signifie chant et chanson est aussi utilisé pour traduire la musique. » (36) That is to say "In the Wolof culture, by the way, there is no term to say 'Music'. The word "woy" which means singing and song is also used to refer to music." (36) This remark that Cissé makes also applies to the songs in the fiction of Morrison, and generally to all cultures of orality. The song "Whose house is this?" punctuates Home and can also be set to music.

The presence of the epigraph song in Home, like the presence of the jazz in Jazz, functions as a subtext upon which Morrison's poetics of intertextuality is written. Through her poetics of intertextuality, Morrison turns upside down the Eurocentric generic division of genres. The intention of Morrison to flip around the convention of genre division is clear from the opening chapter of Home. The narrative is framed in such a way that Frank relates like a storyteller his personal story to a listener, who is nameless and faceless. This nameless and faceless listener is the one who writes down the story of Frank Money. Because of this storytelling dimension, the story of Frank Money can be read as an oral testimony. Home like Beloved or Song of Solomon is grounded on storytelling.

The background story of Home draws on a famous german tale "Hansel and Gretel." The fairy-tale theorist Jack Zipes states that the traditional "Hansel and Gretel" is a story of hope; it is also about escape and home returning. The "Hansel and Gretel" is a famous tale of German origin that dates back to 1812. Hansel and Gretel are a young brother and sister threatened by a cannibalistic witch living in the nearby forest in a house built out of cake and confectionary. And through sneakiness, they succeeded in escaping the witch.

Reading Home in the light of the tale of Hansel and Gretel shows that Home ends in the same way as the tale of Frank and Cee: the protagonists go home where they find peace. But Frank and Cee are not sure to find the same peace and safety that Hansel and Gretel obtain. The tale of Hansel and Gretel is, too, about perseverance. The same theme of perseverance is omnipresent in Home; it is through perseverance, for example, that Frank Money succeeds in finding and freeing his sister. The theme of perseverance is also conveyed through the image of the tree that is still standing despite the fact that it has been hurt many times. Morrison, then, uses a famous tale from world literature to write down through a sort of "oral fiction" the history of estrangement, disillusionment, and incarceration of Frank Money and his community. To be faithful to the logic of Hansel and Gretel tale, Morrison puts her narrator in the posture of a storyteller. The storyteller is an embodiment of the repository of the history and culture of the community much like Beloved epitomizes a received memory.

On balance, we have seen that Morrison's poetics of intertextuality is versatile, pitting itself against different genres and traditions. It engages with other texts from world literature, the national archives, and the African culture. Thereby, Morrison creates a poetics of intertextuality rich enough to measure up to the fiction of great writers from the canon, and yet distinct enough to convey the concerns of her policed community. What Morrison's poetics of intertextuality really teaches is that "The truth is usually in the footnotes, not in the headlines" as a character puts it in David Bradley's The Chaneyville Incident. In other words, the reader has to read the headlines in the light of the footnotes. The various aspects of Morrison's poetics of intertextuality stand for the footnotes without which the grand narrative, the headlines, can't stand.

\section{Conflict of interest statement}

The authors declared that they have no competing interest.

Statement of authorship

The authors have a responsibility for the conception and design of the study. The authors have approved the final article.

\section{Acknowledgments}

The authors would like to thank the editor of IJLLC for their valuable time, support, and advice on completing the current study. 


\section{References}

Alan, J. R. (2012). Creating Memorials, Building Identities: The Politics of Memory in the Black Atlantic. Liverpool: Liverpool University Press.

Baker Jr, H. A. (2013). Blues, ideology, and Afro-American literature: A vernacular theory. University of Chicago Press.

Bakhtin, M. M. (1996). The dialogic imagination. 1981. Austin: Texas UP.

Bakhtin, M. M. (2010). The dialogic imagination: Four essays (Vol. 1). University of texas Press.

Bouchard, D. F., \& Simon, S. (1977). Language, counter-memory, practice. Selected essays and interviews by Michel Foucault.

Bradley, D. (1981). The Chaneyville Incident . New York, Harper and Row.

Byala, G. (2008). The Absurd in Literature. Comparative Literature Studies, 45(3), 398-401.

Camp, J. T., \& Heatherton, C. (Eds.). (2016). Policing the planet: Why the policing crisis led to Black Lives Matter. Verso Books.

Cissé, M. (2010). Parole chantée et communication sociale chez les Wolof du Sénégal. Editions L'Harmattan.

Conrad, J. (2007). Victory: an island tale. Modern library.

Conrad, J. (2008). Typhoon and other Tales. OUP Oxford.

D'Angelo, F. J. (2009). The rhetoric of intertextuality. Rhetoric Review, 29(1), 31-47. https://doi.org/10.1080/07350190903415172

Faris, W. B. (2002). The Question of the Other: Cultural Critiques of Magical Realism. Janus Head, 5(2), $101-119$.

Gates Jr, H. L. (2014). The signifying monkey: A theory of African American literary criticism. Oxford University Press.

Gérard, G. E. N. E. T. T. E. (1982). Palimpsestes. La littérature au second degré. Paris, Editions du Seuil (Points Essais).

Graham, A. (2000). Intertextuality, London and New York.

Gray, F. D. (1998). The Tuskegee syphilis study: The real story and beyond. NewSouth Books.

Guth, D. (1993). A blessing and a burden: the relation to the past in sula," song of solomon" and" beloved". Modern Fiction Studies, 39(3/4), 575-596.

Hirsch, M. (2008). The generation of postmemory. Poetics today, 29(1), 103-128.

Jennings, L. V. D. (2010). Toni Morrison and Idea of Africa. Cambridge U.P.

Landow, G. P. (1997). Hypertext 2.0: The convergence of contemporary critical theory and technology (Parallax: Revisions of Culture and Society Series). Johns Hopkins University Press.

Mahyudi, J., Saryono, D., Siswanto, W., \& Pratiwi, Y. (2017). Construction of visual features of Indonesian digital poetry. International Journal of Linguistics, Literature and Culture, 3(5), 1-13.

Mengel, E., \& Borzaga, M. (Eds.). (2012). Trauma, memory, and narrative in the contemporary South African novel: essays (Vol. 153). Rodopi.

Middleton, J. I. (1993). Orality, literacy, and memory in Toni Morrison's Song of Solomon. College English, 55(1), 64-75.

Mohan, N., \& Kumar, S. S. (2018). From the individual to the historical: a commentary on amitav ghosh as a writer of historical fiction with reference to the glass palace. International Journal of Social Sciences and Humanities, 2(3), 79-85. https://doi.org/10.29332/ijssh.v2n3.203

Morrison, T. (1984). Rootedness: The ancestor as foundation. Black women writers (1950-1980): A critical evaluation, $339-45$.

Morrison, T. (1984). Rootedness: The ancestor as foundation. Black women writers (1950-1980): A critical evaluation, $339-45$.

Morrison, T. (2004). Beloved. First Vintage International Edition.

Morrison, T. (2007). Playing in the Dark. Vintage.

Morrison, T. (2007). The dancing mind. Vintage.

Morrison, T. (2012). Desdemona. Oberon Books.

Morrison, T. Song of Solomon (New York: Signet, 1977). hereafter cited in the text. Compare Benston," Re-Weaving the'Ulysses Scene, 333-34.

Nadel, A. (1988). Invisible criticism: Ralph Ellison and the American canon. University of Iowa Press.

Nora, P. (1989). Between memory and history: Les lieux de mémoire. representations, 7-24.

Phelan, J. (1993). Toward a Rhetorical Reader-Response Criticism: The Difficult, the Stubborn, and the Ending of" Beloved". Modern Fiction Studies, 39(3/4), 709-728.

Sy, O. (2019). Toni morrison's poetics of intertextuality or the supreme art of borrowing. International Journal of Linguistics, Literature and Culture, 5(5), 36-54. https://doi.org/10.21744/ijllc.v5n5.742 
Porter, J. E. (1986). Intertextuality and the discourse community. Rhetoric review, 5(1), 34-47. https://doi.org/10.1080/07350198609359131

Razmi, M., \& Jamali, L. (2012). Magic (al) realism as postcolonial device in Toni Morrison's Beloved. International Journal of Humanities and Social Science, 2(5), 112-119.

Slemon, S. (1988). Magic realism as postcolonial discourse. na.

Visser, I. (2011). Trauma theory and postcolonial literary studies. Journal of Postcolonial Writing, 47(3), 270-282. https://doi.org/10.1080/17449855.2011.569378

Yúdice, G. (1991). Testimonio and postmodernism. Latin American Perspectives, 18(3), 15-31. https://doi.org/10.1177\%2F0094582X9101800302

\section{Biography of Author}

\begin{tabular}{|l|l|l|}
\hline \hline & $\begin{array}{l}\text { Ousseynou Sy earned a Master in English at The University of Texas at Austin (UT } \\
\text { Austin) in 2007 and another Master in Public Affairs at the LBJ School of Public Affairs } \\
\text { at UT Austin. He also worked for five years as a Teaching Assistant in the English } \\
\text { Department at UT Austin teaching American and World literature. Prior to that he } \\
\text { attended Cheikh Anta Diop University in Dakar Senegal where he earned in 2004 a Post- } \\
\text { master degree (a.k.a Diplome d'Etude Approfondie) in British literature. He is a Ph.D in } \\
\text { American literature from Gaston Berger University in Saint-Louis in Senegal. His } \\
\text { research interests are African American literature and Post-colonial African literature, } \\
\text { and international development and relations. He teaches English and Public Policy in } \\
\text { Sahel University Dakar. His publications appeared in Metacritic Journal for Comparative } \\
\text { Studies and Theory, the Ethnic Third World Journal (E3W Review of Books) and in the } \\
\text { following newspapers: Le Soleil, Le Quotidien, and Senego.com. } \\
\text { Email: ousseynousy2002@yahoo.fr / ousseynou2002@ @mail.com }\end{array}$ \\
\hline
\end{tabular}

